Proc. Indian Acad. Sci., Vol. 87A (Chemical Sciences-4), No. 8, August 1978, pp. 281-284, (C) printed in India.

\title{
Preparation and characterization of hydrazinium derivatives
}

K C PATIL, R SOUNDARARAJAN and V R PAI VERNEKER

High Energy Solids Group, Department of Inorganic and Physical Chemistry, Indian Institute of Science, Bangalore 560012

MS received 28 April 1978; revised 22 June 1978

Abstract. A number of simple and complex hydrazinium derivatives have been prepared by the reaction of hydrazine hydrate with ammonium salts. The products were characterized by chemical analysis and infrared spectra.

Keywords. Hydrazinium derivatives; hydrazinates.

\section{Introduction}

Preparation of simple hydrazinium salts is easily accomplished either by neutralization of aqueous hydrazine with corresponding acids, or by double decomposition of hydrazine sulfate with corresponding barium salts (Audrieth and Ogg 1951; Hudson et al 1967 and Mellor 1927). Anhydrous hydrazine is known to react with ammonium salts giving corresponding hydrazinium derivatives (Audrieth and Ogg 1951). However, only few hydrazinium salts have been prepared using anhydrous $\mathrm{N}_{2} \mathrm{H}_{4}$; e.g. $\mathrm{N}_{2} \mathrm{H}_{5} \mathrm{~N}_{3}$ (Muller 1937), $\mathrm{N}_{2} \mathrm{H}_{5} \mathrm{ClO}_{4} \cdot 0.5 \mathrm{H}_{2} \mathrm{O}$ (Stern 1964). $\mathrm{H}_{2} \mathrm{~N}_{5} \mathrm{~F}$ (Glavic and Slivnik 1967) and $\mathrm{N}_{2} \mathrm{H}_{5} \mathrm{NO}_{3}$ (Saad and Detweiler 1969). The use of anhydrous hydrazine in the preparation of hydrazinium derivatives has not been pursued, probably because of its hazardous nature. An attempt was therefore made to prepare hydrazinium derivatives from ammonium salts using hydrazine hydrate. Further, it was thought interesting if this method could be extended to ammonium alums and double salts since, hydrazinium metal sulphates of the general formula; $\left(\mathrm{N}_{2} \mathrm{H}_{5}\right)_{2} \mathrm{M}\left(\mathrm{SO}_{4}\right)_{2}$ where $\mathrm{M}=\mathrm{Mn}, \mathrm{Fe}, \mathrm{Co}, \mathrm{Ni}, \mathrm{Zn}$ and $\mathrm{Cu}$ have been described as antiferromagnetic materials and were prepared by cocrystallisation of metal sulphates with $\mathrm{N}_{2} \mathrm{H}_{6} \mathrm{SO}_{4}$ (Nieuwpoort and Reedijk 1973).

\section{Experimental}

All ammonium salts used in this study were of analytical grade. Hydrazine hydrate (99-100\%) was commercially available and was used as such. Stoichiometric quantities of ammonium salts and hydrazine hydrate were mixed and allowed to react. Ammonium salts dissolved completely with the evolution of ammonia. The resulting solution was allowed to crystallize in a vacuum desiccator over $\mathrm{P}_{2} \mathrm{O}_{5}$. Conversion of ammonium salt to hydrazinium salt was quantitative. Metal $\left(\mathrm{M}=\mathrm{Fe}^{2+}, \mathrm{Co}^{2+}\right.$, 
$\mathrm{Ni}^{2+}$ and $\mathrm{Al}^{3+}$ ) ammonium alums when treated with hydrazine hydrate yield corresponding hydrazinium metal sulphate hydrazinates. The products were characterized by their melting points, infrared spectra and compositions were fixed by hydrazine content as well as metal analyses. Infrared spectra were recorded as nujol mulls and $\mathrm{KBr}$ pellets using Carl-Zeiss UR-10 spectrophotometer. Hydrazine content was determined by volumetric analysis using standard (0.05 M) potassium iodate solution under Andrews conditions (Vogel 1951). Metal contents were determined by EDTA titrations (Welcher 1958).

\section{Results and discussion}

Hydrazine hydrate is an aqueous solution of hydrazine. Hydrazine and water form a constant boiling mixture with a maximum boiling point at $120 \cdot 5^{\circ} \mathrm{C}(771 \mathrm{~mm}$ pressure) corresponding to a mixture containing $58.5 \%$ hydrazine. Reaction between hydrazine and water is represented by the equilibrium:

$$
\mathrm{N}_{2} \mathrm{H}_{4}+\mathrm{H}_{2} \mathrm{O} \rightleftarrows \mathrm{N}_{2} \mathrm{H}_{5}^{+}+\mathrm{OH}^{-} ; \mathrm{K}_{1}=8.5 \times 10^{-7} \text { at } 25^{\circ} \mathrm{C}
$$

The solutions of hydrazine in water are basic and act as reducing agents. The stoichiometry of the reaction of hydrazine hydrate with ammonium salts and alums could be represented by eqs (1) to (4):

$$
\mathrm{NH}_{4} \mathrm{X}+\mathrm{N}_{2} \mathrm{H}_{4} \cdot \mathrm{H}_{2} \mathrm{O} \rightarrow \mathrm{N}_{2} \mathrm{H}_{5} \mathrm{X}+\mathrm{NH}_{3}(\mathrm{~g})+\mathrm{H}_{2} \mathrm{O}(\mathrm{g})
$$

where $\mathrm{X}=\mathrm{F}, \mathrm{Cl}, \mathrm{Br}, \mathrm{I}, \mathrm{NO}_{3}, \mathrm{ClO}_{4}$ and $\mathrm{N}_{3}$

$$
\left(\mathrm{NH}_{4}\right)_{2} \mathrm{Y}+2 \cdot \mathrm{N}_{2} \mathrm{H}_{4} \cdot \mathrm{H}_{2} \mathrm{O} \rightarrow\left(\mathrm{N}_{2} \mathrm{H}_{5}\right)_{2} \mathrm{Y}+2 \mathrm{NH}_{3}(\mathrm{~g})+2 \mathrm{H}_{2} \mathrm{O}(\mathrm{g})
$$

where $\mathrm{Y}=\mathrm{SO}_{4}, \mathrm{C}_{2} \mathrm{O}_{4}$

$$
\begin{aligned}
& \left(\mathrm{NH}_{4}\right)_{2} \mathrm{M}\left(\mathrm{SO}_{4}\right)_{2} \cdot 6 \mathrm{H}_{2} \mathrm{O}+5 \cdot \mathrm{N}_{2} \mathrm{H}_{4} \cdot \mathrm{H}_{2} \mathrm{O} \cdot \rightarrow\left(\mathrm{N}_{2} \mathrm{H}_{5}\right)_{2} \mathrm{M}\left(\mathrm{SO}_{4}\right)_{2} \cdot 3 \mathrm{~N}_{2} \mathrm{H}_{4}+ \\
& 2 \mathrm{NH}_{3}(\mathrm{~g})+11 \mathrm{H}_{2} \mathrm{O}(\mathrm{g})
\end{aligned}
$$

where $\mathrm{M}=\mathrm{Fe}$, $\mathrm{Co}$ and $\mathrm{Ni}$

$$
\begin{aligned}
& \mathrm{NH}_{4} \mathrm{Al}\left(\mathrm{SO}_{4}\right)_{2} \cdot 12 \mathrm{H}_{2} \mathrm{O}+7 \mathrm{~N}_{2} \mathrm{H}_{4} \cdot \mathrm{H}_{2} \mathrm{O} \rightarrow \mathrm{N}_{2} \mathrm{H}_{5} \mathrm{Al}\left(\mathrm{SO}_{4}\right)_{2} \cdot 6 \mathrm{~N}_{2} \mathrm{H}_{4}+ \\
& \quad \mathrm{NH}_{3}(\mathrm{~g})+19 \mathrm{H}_{2} \mathrm{O}(\mathrm{g})
\end{aligned}
$$

Simple hydrazinium derivatives are quite hygroscopic and need handling in dry atmosphere. Analytical data of all the compounds prepared are presented in table 1. The observed melting points of the simple hydrazinium salts are in good agreement with the literature values. The hydrazine contents correspond to the formulae. The compositions of the hydrazinate complexes were fixed by the hydrazine contents and metal analysis. It is interesting to observe that in metal ammonium alums in addition to substitution of $\mathrm{NH}_{4}^{+}$ions by $\mathrm{N}_{2} \mathrm{H}_{5}{ }^{+}$ions the water of crystallisation was 
Table 1. Analytical data of hydrazinium derivatives

\begin{tabular}{|c|c|c|c|c|c|c|}
\hline \multirow[b]{2}{*}{ Compound } & \multirow[b]{2}{*}{$\mathrm{MP} *{ }^{\circ} \mathrm{C}$} & \multicolumn{2}{|c|}{$\%$ Hydrazine } & \multicolumn{2}{|c|}{$\%$ Metal } & \multirow{2}{*}{$\begin{array}{l}\text { I.R. Absorption } \\
\nu \mathrm{N}-\mathrm{N} \mathrm{cm}^{-1}\end{array}$} \\
\hline & & Observed & $\begin{array}{l}\text { Theore- } \\
\text { tical }\end{array}$ & Observed & $\begin{array}{c}\text { Theoro- } \\
\text { tical }\end{array}$ & \\
\hline $\mathrm{N}_{2} \mathrm{H}_{6} \mathrm{~F}$ & $120(-)$ & $61 \cdot 11$ & $61 \cdot 53$ & & & 980,960 \\
\hline $\mathrm{N}_{2} \mathrm{H}_{6} \mathrm{Cl}$ & $90(89)$ & $47 \cdot 0$ & $46 \cdot 72$ & & & 970 \\
\hline $\mathrm{N}_{2} \mathrm{H}_{6} \mathrm{Br}$ & $80(80)$ & $28 \cdot 07$ & $28 \cdot 32$ & & & 965 \\
\hline $\mathrm{N}_{2} \mathrm{H}_{8} \mathrm{I}$ & $125(124-126)$ & $20 \cdot 60$ & $20 \cdot 51$ & & & 970,965 \\
\hline $\mathrm{N}_{2} \mathrm{H}_{5} \mathrm{NO}_{3}$ & $62(62-91)$ & $33 \cdot 61$ & $33 \cdot 66$ & & & 960 \\
\hline $\mathrm{N}_{2} \mathrm{H}_{5} \mathrm{~N}_{3}$ & $75(75.4)$ & $42 \cdot 50$ & $42 \cdot 62$ & & & 960 \\
\hline $\mathrm{N}_{2} \mathrm{H}_{5} \mathrm{ClO} \cdot \mathrm{O} \cdot 5 \mathrm{H}_{2} \mathrm{O}$ & - & $22 \cdot 38$ & $22 \cdot 61$ & & & 960 \\
\hline$\left(\mathrm{N}_{2} \mathrm{H}_{8}\right)_{2} \mathrm{SO}$ & $85(85)$ & $39 \cdot 36$ & $39 \cdot 45$ & & & 970,965 \\
\hline$\left(\mathrm{N}_{2} \mathrm{H}_{6}\right)_{2} \mathrm{C}_{2} \mathrm{O}_{4}$ & $150(148)$ & $41 \cdot 50$ & 41.54 & & & 970,965 \\
\hline$\left(\mathrm{N}_{2} \mathrm{H}_{6}\right)_{2} \mathrm{Fe}\left(\mathrm{SO}_{4}\right)_{2} \cdot 3 \mathrm{~N}_{2} \mathrm{H}_{4}$ & - & $38 \cdot 6.3$ & $39 \cdot 04$ & $13 \cdot 60$ & $13 \cdot 63$ & 1010,995 \\
\hline$\left(\mathrm{N}_{2} \mathrm{H}_{5}\right)_{2} \mathrm{Co}\left(\mathrm{SO}_{4}\right)_{2} \cdot 3 \mathrm{~N}_{2} \mathrm{H}_{4}$ & - & 39.92 & $38 \cdot 74$ & $14 \cdot 25$ & $14 \cdot 27$ & 1000,990 \\
\hline$\left(\mathrm{N}_{2} \mathrm{H}_{5}\right)_{2} \mathrm{Ni}\left(\mathrm{SO}_{4}\right)_{2} \cdot 3 \mathrm{~N}_{3} \mathrm{H}_{6}$ & - & $38 \cdot 78$ & $38 \cdot 74$ & $14 \cdot 25$ & $14 \cdot 28$ & 1000,990 \\
\hline $\mathrm{N}_{2} \mathrm{H}_{6} \mathrm{Al}\left(\mathrm{SO}_{4}\right)_{2} \cdot 6 \mathrm{~N}_{2} \mathrm{H}_{4}$ & - & $51 \cdot 00$ & $50 \cdot 44$ & $6 \cdot 12$ & 6.08 & 1020,990 \\
\hline
\end{tabular}

-Melting points in the parentheses are from I ange's Hand Book of Chemistry 11th Edition 1973 (New York: McGraw-Hill Book Company) p. 4-57.

also quantitatively replaced by hydrazine molecules. The number of hydrazine molecules is half the number of water molecules in the alums. In reactions (3) and (4) although ammonia and water are formed, there was no evidence of the hydrolysis of the metal ions.

Infrared spectra has been useful in identifying $\mathrm{N}_{2} \mathrm{H}_{4}, \mathrm{~N}_{2} \mathrm{H}_{5}^{+}$and $\mathrm{N}_{2} \mathrm{H}_{6}^{+2}$ which show characteristic absorption of $\nu \mathrm{N}-\mathrm{N} \sim 880,960$ and $1025 \mathrm{~cm}^{-1}$ respectively (Braibanti et al 1968). Hydrazinium derivatives show characteristic absorption of $\mathrm{N}_{2} \mathrm{H}_{5}{ }^{+}$ $\sim 965 \mathrm{~cm}^{-1}$ (table 1). The hydrazinium metal sulphate hydrazinate show a doublet $\sim 1000 \mathrm{~cm}^{-1}$ which could be assigned to $\nu \mathrm{N}-\mathrm{N}$ of $\mathrm{N}_{2} \mathrm{H}_{5}{ }^{+}$similar to that observed in $\left(\mathrm{N}_{2} \mathrm{H}_{5}\right)_{2} \mathrm{M}\left(\mathrm{SO}_{4}\right)_{2}$ (Nieuwpoort and Reedijk 1973) as well as $\nu \mathrm{N}-\mathrm{N}$ the coordinated hydrazine (Sacconi and Sabatini 1963).

\section{Conclusions}

(a) Hydrazine hydrate reacts with simple ammonium salts to yield corresponding hydrazinium derivatives.

(b) Hydrazine hydrate reacts with metal ammonium alums substituting $\mathrm{NH}_{4}{ }^{+}$jons by $\mathrm{N}_{2} \mathrm{H}_{5}{ }^{+}$ions and replacing water of crystallisation by hydrazine molecules.

This method of preparation of hydrazinium derivatives is simple and safe.

\section{References}

Audrieth L F and Ogg B A 1951 The chemistry of hydrazine (New York: John Wiley) p. 168, 200 Braibanti A I, Dallavalle F, Pellinghelli H A and Leporati E 1968 Inorg. Chem. 71430

Glavic P and Slivnik J 1967 Monatsh Chem. 981878

Hudion G H. Spzncer R C H and Stern J P 1967 Supplement to Mellor's comprehensive treatise on inorganic and theoretical chemistry Suppl. II N (Part li) (London: Longmans Green) Vol. 8 p. 84 
Mellor J W 1927 A comprehensive treatise on inorganic and theoretical chemistry (London: Longmans Green) Vol. 8 p. 322

Muller E 1937 Ger Patent P 634688 Chem. Abstr. 31511

Nieuwpoort A and Reedijk J 1973 Inorg. Chim. Acta 7323

Saad M A and Detweiler M B 1969 AIAA J. 71588

Sacconi L and Sabatini A 1963 J. Inorg. Nucl. Chem. 251389

Stern D R 1964 US Patent 3, 135, 997, Chem. Abstr. 61 p. $9198 \mathrm{~g}$

Vogel A I 1951 A text Book of quantitative inorganic analysis (London: Longmans Green (p. 365)

Welcher F J 1958 The analytical uses of ethylene diamine tetraacetic acid (New York: Van Nostrand) 